\title{
An experimentalist's challenge: when artifacts of intervention interact with treatments
}

\author{
Charles H. Peterson ${ }^{1}$, R. Black ${ }^{2}$ \\ ${ }^{1}$ University of North Carolina at Chapel Hill, Institute of Marine Sciences, Morehead City, North Carolina 28557, USA \\ ${ }^{2}$ Department of Zoology, University of Western Australia, Nedlands, Western Australia 6009, Australia
}

\begin{abstract}
A common, usually implicit, assumption of the present epistemology of experimental natural science is the following: so long as any necessary experimental intervention is identically applied to each treatment, then the effects of artifacts of that intervention will be constant across all treatments. This constancy of artifacts of intervention thus allows unbiased assessment of differences between and among treatments because effects of any such artifacts contribute equally to each treatment and therefore cancel out in contrasts. Unfortunately, this assumption will be violated whenever an artifact of intervention and the experimental treatment interact. As one illustration of the lack of appreciation of this assumption, we review those marine ecological studies that employ tethering of mobile prey organisms as a technique by which to assess the relative intensity of predation as a function of changing habitat. That review reveals that: (1) only $55 \%$ of the 22 studies even include discussion of artifacts of tethering; (2) only $9 \%$ acknowledge the possibility that the magnitude or direction of the between-habitat difference in predation as estimated from mortality of prey on tethers could be inaccurate if the artifactual enhancement of predation rate induced by tethering is not constant across habitats; and (3) no study actually tests the assumption that tethering artifacts are independent of habitat (the experimental treatment). If different consumers are present in different proportions in the habitats being compared, as is often the case, it is possible and even likely that the magnitude of artifactual enhancement of predation induced by tethering otherwise mobile organisms will fail to remain constant across habitats. This represents but one example of a general lack of recognition that artifacts of experimental intervention may interact with treatments, a concern that applies also to use of enclosures and cages in field experiments and aquaria and containers in the laboratory. Because the experimental intervention that induces the artifact is typically essential for conduct of the experiment, clever indirect techniques may be needed to allow experimentalists to assess the importance of nonadditive artifacts of intervention.
\end{abstract}

KEY WORDS: Epistemology - Experimental design - Predator behaviour - Tethering - Treatmentdependent artifacts

\section{INTRODUCTION TO THE PROBLEM}

To conduct an experiment in a natural science is to intervene in the natural system. Such intervention is now appropriately viewed as the most unequivocal means of testing process-oriented hypotheses (e.g. Connell 1974, Paine 1977, Underwood 1985, Hairston 1989), yet runs the risk of introducing artifacts that may bias the outcomes (e.g. Dayton 1979, Underwood 1986). The problem of potential artifacts of experimentation is most commonly recognized when the inter- ventions required are grossly invasive and obvious, such as when experiments are conducted within the artificiality of laboratory containers or when cages or enclosures are utilized in ecological field experiments (e.g. Connell 1974, Peterson 1979, Dayton \& Oliver 1980). Nevertheless, the mere presence of an observer making observations also has potential for altering the system that is being observed, as acknowledged by Underwood (1985) and as widely appreciated by animal behaviorists and behavioral ecologists (e.g. Caine 1990). 
The epistemology of experimental ecology currently provides a widely accepted prescription for how to assess the role of artifacts of intervention. Because many experimental artifacts are created by behavioral responses to intervention (see Chapman 1986), the concerns expressed in this paper apply more commonly but not exclusively to animal ecology. Two categories of experiments should first be distinguished: those that are performed by use of constraints of some sort, such as laboratory aquaria or containers and field enclosures or cages, and those where (except for observation) only the experimental treatments require intervention. The problem of interacting experimental treatments and artifacts that we address in this paper applies equally to both categories of experiments, but the logic of how controls for intervention are utilized may differ somewhat.

For experiments conducted within enclosures (or, more broadly, through use of any constraint to movement), if the intervention of enclosing is applied identically across all experimental treatments and controls so that only the experimental treatment itself varies, then current epistemological practice would imply that any artifactual effects introduced by enclosing are also held constant (e.g. Connell 1974). It would then follow that comparisons between and among experimental treatments and controls are unaffected by the artifacts resulting from enclosure because a constant artifact of intervention would simply cancel out in making any contrast. Furthermore, if it were possible, as it ordinarily is, to erect controls for evaluating the direction and magnitude of biases of intervention (for example, by comparing the performance of animals maintained inside the required experimental enclosures at natural, ambient density to that of identical animals roaming free at that same ambient density), one should employ such controls. Results of these controls would then be used to estimate the direction and magnitude of the artifact caused by enclosing and thus to assess the conditions under which the experiments were conducted (see examples of this practice in Kennelly 1983, Peterson \& Beal 1989, and Peterson \& Black 1993). Such a usage of controls for possible artifacts of experimental intervention reflects the perception that even though treatments may be compared if artifacts are all equal in every treatment, it is nonetheless possible that the experiments were conducted under an unnatural domain of conditions dictated by consequences of experimental intervention. The controls for effects of artifacts would thus be used to evaluate how natural the experimental conditions were.

For experiments not requiring enclosures or containers or some other constraints to movement, controls are nonetheless appropriately employed to allow separation of the artifacts of intervention from the effects of the experimental treatment itself. For example, in situ transplants are commonly used as controls in comparisons to unmanipulated plants to assess the effects of the disturbance of excavation, transportation, and replanting that are otherwise confounded within the responses to environment in a transplant experiment (e.g. Rabinowitz 1978, Petraitis 1982, Chapman 1986, Underwood 1986). Thus, for experiments done without enclosures, controls are employed to separate confounded artifacts induced by intervention and true responses to the experimental treatment. Following these epistemological procedures now meets the highest standards of rigor in ecology.

Unfortunately, the Iogical basis underlying this current practice for dealing with the potential biases from artifacts of experimental intervention is incomplete. The argument implicitly assumes without requiring justification by proper test or compelling theory that the effects of artifacts of experimental intervention are constant across all treatments just because the intervention itself is identically applied to all treatments. It is entirely possible to induce non-additive artifacts of intervention that vary with experimental treatment, thereby potentially confounding any comparison between treatments and/or controls that does not evaluate and adjust for treatment-specific differences in artifacts.

We know of only one study that has adequately tested whether an artifact of experimental intervention interacted with the treatment. In an elegant series of experiments, Kennelly (1983) showed that settlement plates attached to and thereby elevated above the natural rock surface on the intertidal seafloor exhibited greater amounts of algal cover after a period of colonization than cleared patches on the natural rock or than recessed settlement plates flush with the bottom. This difference was presumably caused by the elevation inhibiting the access of amphipods and other small grazers or else by greater flows at the higher elevation enhancing spore settlement or nutrient delivery. When Kennelly excluded predatory fish by caging them off the settlement surfaces of each type, he showed that algal cover was substantially reduced when fish were excluded because of subsequent increases in densities of their prey, the invertebrate grazers like amphipods. In addition, Kennelly (1983) also demonstrated that the artifact caused by elevating settlement plates above the rock surface was not constant across caged and uncaged treatments, so this artifact interacted with the experimental treatment.

We do not pretend to know how widespread the problem of non-additivity of artifacts is or how seriously it actually compromises interpretations of ecological experiments. Our intent is to identify explicitly this now implicit assumption of additivity that has 
remained an unarticulated element of the epistemology of experimental ecology, to clarify the issue with illustrations from marine ecology, and to suggest potential approaches that experimentalists might take to assess the scope of this problem. Like Dayton (1979), Hurlbert (1984), and Underwood (1986), we hope thereby to improve the epistemological basis of experimental ecology.

\section{ILLUSTRATION OF THE PROBLEM: TETHERING EXPERIMENTS}

To clarify this challenge that experimentalists face, we conduct here a review of all aquatic ecological experiments known to us in which tethering was employed as a device to constrain the movement of prey so that relative rates of predation could be experimentally estimated for different habitats. For each of the 22 papers that we surveyed, Table 1 lists: (1) the prey organism that was tethered; (2) the habitat factor(s) contrasted in the experiment; (3) the main conclusion(s) from the tethering experiment; (4) whether any discussion of simple (first-order) artifacts of tether- ing was included; (5) whether mention was made of the possible interaction between tethering and the habitat treatment; and (6) whether any test of either simple or higher-order (interaction between tethering and experimental treatment) artifacts was conducted. Although this survey may not be complete, its bias is likely to be one of overrepresentation of papers in those journals with better reputations (Ecology, Ecological Monographs, Oecologia, Marine Ecology Progress Series, Journal of Experimental Marine Biology and Ecology) rather than the converse. Some papers (e.g. Power \& Mathews 1983) employed tethering of predators to act as scarecrows rather than to estimate relative rates of predation on prey: such studies were excluded from our tabulation. Almost all tethering was done to constrain movements of actively mobile prey animals (crustaceans, fishes, echinoderms, molluscs), but 3 papers included in our survey tethered plant parts (seeds or leaves) that would be passively transported by tidal currents in the absence of constraints

Our survey (Table 1 ) reveals that a majority (but only $55 \%$ ) of papers that used tethering of mobile prey to estimate relative rates of predation recognized and

Table 1. Assessment of tethering artifacts in tethering experiments, designed to assess how relative rates of prey consumption vary among habitats (the experimental treatments)

\begin{tabular}{|c|c|c|c|c|c|c|}
\hline $\begin{array}{l}\text { Organism } \\
\text { tethered }\end{array}$ & $\begin{array}{l}\text { Factor(s) } \\
\text { manipulated } \\
\text { (treatment) }\end{array}$ & Results & $\begin{array}{l}\text { Discussion } \\
\text { of simple } \\
\text { tethering } \\
\text { artifacts? }\end{array}$ & $\begin{array}{l}\text { Mention of pos- } \\
\text { sible interaction } \\
\text { artifact between } \\
\text { tethering and } \\
\text { treatment? }\end{array}$ & $\begin{array}{l}\text { Test of } \\
\text { either } \\
\text { artifact? }\end{array}$ & Source \\
\hline $\begin{array}{l}\text { Small majid, } \\
\text { xanthid, portunid, } \\
\text { and hermit crabs }\end{array}$ & Plant cover & $\begin{array}{l}\text { Predation was greater } \\
\text { in bare sand than in } \\
\text { turtlegrass or drift algae }\end{array}$ & No & No & No & $\begin{array}{l}\text { Heck \& } \\
\text { Thoman (1981) }\end{array}$ \\
\hline Turban snails & $\begin{array}{l}\text { Water depth; } \\
\text { kelp cover }\end{array}$ & $\begin{array}{l}\text { Predation was greater } \\
\text { at deeper depth and } \\
\text { where vegetation was } \\
\text { cleared }\end{array}$ & Yes & No & No & Watanabe (1984) \\
\hline $\begin{array}{l}\text { Juvenile grunts } \\
\text { (fish) }\end{array}$ & $\begin{array}{l}\text { Distance from } \\
\text { reef }\end{array}$ & $\begin{array}{l}\text { Time to disappearance } \\
\text { was shorter closer to } \\
\text { reef }\end{array}$ & No & No & No & Shulman (1985) \\
\hline $\begin{array}{l}\text { Bivalve, sea } \\
\text { urchin, and } \\
\text { ophiuroid }\end{array}$ & $\begin{array}{l}\text { Inside vs outside } \\
\text { a mussel bed }\end{array}$ & $\begin{array}{l}\text { Predation was much } \\
\text { higher on bare sub- } \\
\text { stratum without mussels }\end{array}$ & $\mathrm{No}^{\mathrm{a}}$ & No & No ${ }^{b}$ & Witman (1985) \\
\hline Juvenile lobsters & $\begin{array}{l}\text { Plant cover; } \\
\text { day/night }\end{array}$ & $\begin{array}{l}\text { Predation was greater } \\
\text { on bare sand than in } \\
\text { algal clumps or in } \\
\text { seagrass and least in } \\
\text { algal beds. No day/night } \\
\text { differences }\end{array}$ & Yes & No & No & $\begin{array}{l}\text { Herrnkind \& } \\
\text { Butler (1986) }\end{array}$ \\
\hline Ophiuroid & $\begin{array}{l}\text { An isolated habitat } \\
\text { with predator im- } \\
\text { poverishment vs } \\
\text { predator-rich habitats }\end{array}$ & $\begin{array}{l}\text { Predation rate was } \\
\text { far lower at isolated } \\
\text { habitat }\end{array}$ & Yes & No & No & Aronson (1987) \\
\hline
\end{tabular}


Table 1 (continued)

\begin{tabular}{|c|c|c|c|c|c|c|}
\hline $\begin{array}{l}\text { Organism } \\
\text { tethered }\end{array}$ & $\begin{array}{l}\text { Factor(s) } \\
\text { manipulated } \\
\text { (treatment) }\end{array}$ & Results & $\begin{array}{l}\text { Discussion } \\
\text { of simple } \\
\text { tethering } \\
\text { artifacts? }\end{array}$ & $\begin{array}{l}\text { Mention of pos- } \\
\text { sible interaction } \\
\text { artifact between } \\
\text { tethering and } \\
\text { treatment? }\end{array}$ & $\begin{array}{l}\text { Test of } \\
\text { either } \\
\text { artifact? }\end{array}$ & Source \\
\hline $\begin{array}{l}\text { Spider, mud, } \\
\text { grapsid, hermit, } \\
\text { portunid crabs }\end{array}$ & $\begin{array}{l}\text { Seagrass presence; } \\
\text { geography, season, } \\
\text { year }\end{array}$ & $\begin{array}{l}\text { Predation risk was } \\
\text { greater outside } \\
\text { seagrass; magnitude } \\
\text { of difference varied } \\
\text { with place, season, year }\end{array}$ & Yes & No & No & $\begin{array}{l}\text { Heck \& Wilson } \\
(1987)\end{array}$ \\
\hline $\begin{array}{l}\text { Mangrove } \\
\text { leaves }\end{array}$ & $\begin{array}{l}\text { Contrast of } \\
\text { tethered leaves } \\
\text { to leaves in } \\
\text { mesh bags; } \\
\text { day/night }\end{array}$ & $\begin{array}{l}\text { Dry weight of leaves } \\
\text { declined more rapidly } \\
\text { for tethered than bagged } \\
\text { leaves; removal rates were } \\
\text { higher in day }\end{array}$ & Yes & No & No & Robertson (1986) \\
\hline $\begin{array}{l}\text { Mangrove } \\
\text { propagules }\end{array}$ & $\begin{array}{l}\text { Mangrove species; } \\
\text { abundance of adults } \\
\text { in canopy }\end{array}$ & $\begin{array}{l}\text { Predation by crabs } \\
\text { varied with species } \\
\text { of propagule and was } \\
\text { greatest where adult } \\
\text { trees were rare }\end{array}$ & No & No & No & Smith (1987a) \\
\hline $\begin{array}{l}\text { Mangrove } \\
\text { propagules }\end{array}$ & $\begin{array}{l}\text { Elevation within } \\
\text { the intertidal zone; } \\
\text { presence/absence } \\
\text { of adult mangroves }\end{array}$ & $\begin{array}{l}\text { Predation was greatest } \\
\text { where adult trees were } \\
\text { rare; some effect of slower } \\
\text { predation detected at low } \\
\text { intertidal elevation }\end{array}$ & I & No & No & Smith $(1987 b)$ \\
\hline Blue crabs & Eelgrass cover & $\begin{array}{l}\text { Predation rate was } \\
\text { greater on bare sand } \\
\text { than in eelgrass }\end{array}$ & Yes & No & No & $\begin{array}{l}\text { Wilson et al. } \\
(1987)\end{array}$ \\
\hline $\begin{array}{l}5 \text { species of } \\
\text { ophiuroids }\end{array}$ & $\begin{array}{l}\text { Species of ophiuroid } \\
\text { (choice test) }\end{array}$ & $\begin{array}{l}\text { The } 5 \text { species were } \\
\text { consumed at differential } \\
\text { rates by natural predator } \\
\text { assemblage }\end{array}$ & No & No & No & Aronson (1988) \\
\hline $\begin{array}{l}\text { Mummichog } \\
\text { fish }\end{array}$ & Creek habitat & $\begin{array}{l}\text { Predation rate } \\
\text { ('encounter rate') was } \\
\text { greater in erosional than } \\
\text { in depositional sites }\end{array}$ & Yes & No & No & $\begin{array}{l}\text { McIvor \& Odum } \\
\text { (1988) }\end{array}$ \\
\hline $\begin{array}{l}\text { Mummichog } \\
\text { fish }\end{array}$ & Vegetation cover & $\begin{array}{l}\text { Predation was more } \\
\text { intense where sub- } \\
\text { merged aquatic } \\
\text { vegetation was cleared }\end{array}$ & No & No & No & $\begin{array}{l}\text { Rozas \& Odum } \\
(1988)\end{array}$ \\
\hline 2 ophiuroids & $\begin{array}{l}\text { Inside dense } \\
\text { ophiuroid beds vs } \\
\text { on rocky reefs }\end{array}$ & $\begin{array}{l}\text { Predation potential was } \\
\text { greater on rocky reefs } \\
\text { than in flat brittle-star beds }\end{array}$ & No & No & Nob & Aronson (1989) \\
\hline $\begin{array}{l}\text { Large bay } \\
\text { scallops }\end{array}$ & Plant cover & $\begin{array}{l}\text { Mortality was greater } \\
\text { on unvegetated flat } \\
\text { than inside seagrass }\end{array}$ & Yes & Yes & No & $\begin{array}{l}\text { Peterson et al. } \\
\text { (1989) }\end{array}$ \\
\hline $\begin{array}{l}\text { Juvenile } \\
\text { lobsters }\end{array}$ & $\begin{array}{l}\text { Substratumi } \\
\text { tethering }\end{array}$ & $\begin{array}{l}\text { Tethering induced } \\
\text { changes in behavior in } \\
\text { mud, but not in cobble } \\
\text { or peat }\end{array}$ & Yes & No & Yes & $\begin{array}{l}\text { Barshaw \& Able } \\
(1990 a)\end{array}$ \\
\hline $\begin{array}{l}\text { Blue and lady } \\
\text { crabs }\end{array}$ & $\begin{array}{l}\text { Bottom habitat; } \\
\text { crab size and } \\
\text { species }\end{array}$ & $\begin{array}{l}\text { Small blue crabs in sand } \\
\text { showed lower survival } \\
\text { than any other size or } \\
\text { species in any habitat }\end{array}$ & Yes & No & No & $\begin{array}{l}\text { Barshaw \& Able } \\
(1990 \mathrm{~b})\end{array}$ \\
\hline $\begin{array}{l}\text { Juvenile blue } \\
\text { crabs }\end{array}$ & Bottom habitat & $\begin{array}{l}\text { Predation was lower in } \\
\text { eelgrass and Ulva than in } \\
\text { unvegetated habitats }\end{array}$ & No & No & No & $\begin{array}{l}\text { Wilson et al. } \\
(1990)\end{array}$ \\
\hline
\end{tabular}


Table 1 (continued)

\begin{tabular}{|c|c|c|c|c|c|c|}
\hline $\begin{array}{l}\text { Organism } \\
\text { tethered }\end{array}$ & $\begin{array}{l}\text { Factor(s) } \\
\text { manipulated } \\
\text { (treatment) }\end{array}$ & Results & $\begin{array}{l}\text { Discussion } \\
\text { of simple } \\
\text { tethering } \\
\text { artifacts? }\end{array}$ & $\begin{array}{l}\text { Mention of pos- } \\
\text { sible interaction } \\
\text { artifact between } \\
\text { tethering and } \\
\text { treatment? }\end{array}$ & $\begin{array}{l}\text { Test of } \\
\text { either } \\
\text { artifact? }\end{array}$ & Source \\
\hline $\begin{array}{l}\text { Juvenile bay } \\
\text { scallops }\end{array}$ & $\begin{array}{l}\text { Elevation above } \\
\text { bottom }\end{array}$ & $\begin{array}{l}\text { Predation was greater } \\
\text { at bottom than at } 15 \mathrm{~cm} \\
\text { elevation; growth was } \\
\text { less at } 10 \mathrm{~cm} \text { than at lower } \\
\text { or higher elevations }\end{array}$ & No & No & No & $\begin{array}{l}\text { Ambrose \& } \\
\text { Irlandi (1992) }\end{array}$ \\
\hline $\begin{array}{l}\text { Juvenile } \\
\text { lobsters }\end{array}$ & $\begin{array}{l}\text { Bottom habitat; } \\
\text { prey size }\end{array}$ & $\begin{array}{l}\text { Predation risk was } \\
\text { greater on bare hard } \\
\text { substratum and mud than } \\
\text { in cobble; predation was } \\
\text { greater on small lobsters }\end{array}$ & Yes & No & $\mathrm{No}^{b}$ & $\begin{array}{l}\text { Wahle \& Steneck } \\
\text { (1992) }\end{array}$ \\
\hline $\begin{array}{l}\text { Grass shrimp, } \\
\text { blue crabs, } \\
\text { mummichogs }\end{array}$ & Water depth & $\begin{array}{l}\text { Predation was greater for } \\
\text { each species in deepest } \\
\text { than in shallowest of } \\
3 \text { depths }\end{array}$ & Yes & Yes & No & Ruiz et al. (1993) \\
\hline \multicolumn{7}{|c|}{$\begin{array}{l}\text { ' There is discussion and a test of the possible effects of piercing arms of ophiuroids to attach the tether but no discussion of } \\
\text { the artifacts associated with the tether itself } \\
\text { b Tests of whether organisms escaped tethers and whether disappearance implied mortality were conducted, but no tests of } \\
\text { artifacts of tethering on predation itself }\end{array}$} \\
\hline
\end{tabular}

discussed the possibility that use of tethers created a bias in estimates of absolute rates of predation. Those papers that did acknowledge this simple artifact of tethering tended to respond to this possibility by referring to results as predation potential or relative rates of predation, predation risk, or predator-prey encounters. By constraining movements of mobile prey and occasionally inducing attention-attracting behaviors, tethering seems likely to enhance observed rates of predation above those that untethered prey experience. This expectation is supported and acknowledged in all cases where papers provide sufficient information to reach a conclusion about the direction of the simple, first-order artifact of tethering (e.g. Watanabe 1984, Barshaw \& Able 1990a, Ruiz et al. 1993). In most published tethering experiments, absolute rates of predation are extremely high over very short intervals of time (typically $24 \mathrm{~h}$ or less), implying that the upwards bias to absolute rates of predation is often quite large. The magnitude of this simple tethering bias is best evaluated by Watanabe (1984), who showed that observed rates of predation on tethered Tegula snails are grossly inconsistent with natural rates of predation as estimated by the abundance and feeding rate of the seastar predators.

The use of results from tethering experiments designed to compare relative rates of predation between and among habitats would be well justified provided that the artifactual enhancement of predation by teth- ering remained constant across all habitats to be compared. This implicit assumption of no higher-order artifact (i.e. no interaction between tethering effect and habitat) is acknowledged in only 2 of the 22 studies (Table 1). Perhaps the most illuminating demonstration of the widespread failure even to recognize that additivity of artifacts of intervention underlies the present epistemology of tethering experiments can be found in a quote from Aronson (1987): in response to a concern over whether tethering of prey produces artifacts in contrasts of predation among sites because of the novel stimulus of a tethered prey, he responds that the experiment is controlled in the sense that the same stimulus is presented at each site'.

There are numerous reasons to suppose that the magnitude of the tethering bias might be expected to vary among habitat treatments. For example, if different predators dominate in different habitats, the magnitude of the tethering bias would be expected to change with habitat, biasing the magnitude and even possibly the direction (rank order) of the estimated differences among habitats in relative predation rates. For example, tethering a mobile organism may render it susceptible to predation by a consumer that ordinarily does not possess the mobility and ability to capture that organism. The artifactual enhancement in predation that results from such an effect of tethering could be large and could easily differ among habitat treatments if this newly enabled consumer varies in impor- 
tance among habitats. For example, Wilson et al. (1990) admit that different types of predators may be involved in the different habitats that they studied, although their study resembles most others that have employed tethering experiments in that complete and accurate assessments of the predators involved are lacking. Studies using video or time-lapse cameras (Witman 1985, Wahle \& Steneck 1992) represent those with the best understanding of the actual predators involved and thus would allow the most complete retrospective evaluation of the degree to which artifacts of tethering may have varied between habitat treatments.

Only 1 tethering study of the 22 reviewed (Table 1 ) actually printed results of explicit tests to evaluate the role of artifacts of tethering on predation risk, and even it assessed predation risk indirectly (Barshaw \& Able 1990a). These tests evaluated the behavioral differences between tethered and untethered juvenile lobsters in each of 3 substrata. The authors concluded from observing differences in burrowing behavior between tethered and untethered lobsters in mud but not in cobble or peat that, because burrowing may alter risk of predation, species-specific evidence is needed to interpret with caution absolute rates of predation observed in experiments that rely upon tethering experiments. The authors thus used their results only to comment upon the simple artifact of tethering: they failed to realize that the real significance of their study lies in its implication of a complex artifact. Assuming that burrowing behavior does relate to predation risk, the demonstration that the artifactual effect of tethering varies with habitat represents evidence of a non-additive artifact, which would confound any comparison of relative predation rates among habitats. Unfortunately, this study did not actually evaluate the relationship between burrowing behavior and predation rate or recognize the relevance of the results to the question of additivity of artifacts, but it does represent an example of how to address in the future the problem of interaction between artifacts of tethering and habitat treatment.

\section{RESOLUTION OF THE PROBLEM}

The need for addressing and resolving the problem of potential non-additivity of artifacts depends upon its incidence and its consequences. In the absence of extensive empirical tests of additivity of experimental artifacts in the literature, we have no set of examples that could provide the basis for an inductive approach to assessing the significance of this problem. The deductive approach using theory of community ecology to predict incidence and magnitude is not yet applicable, in part because of present inadequacies in our understanding of complex interactions in community ecology. This question of additivity of artifacts may be considered a subset of the larger fundamental set of questions on the relative importance of indirect vs direct interactions and on higher-order vs first-order effects in ecological systems. Many experimentalists (e.g. Davidson et al. 1984, Hay 1986, Schmitt 1987 Peterson \& Black 1988) and theoreticians alike (e.g. Vandermeer 1980, Abrams 1987, Pilette 1989, Schoener 1993) have been devoting effort to understand the roles played by multiple factors and non-linear effects. Future synthesis of this ongoing work may provide insight into the question of what conditions are likely to produce interactions between experimental artifacts and treatments of various sorts.

General predictions about the consequences of ignoring potential non-additivity of experimental artifacts are difficult to develop in the absence of empirical data and compelling theory. Our driving motivation in preparing this paper is not to challenge specific conclusions from past experimental studies but to make explicit a previously implicit assumption in experimental ecology and thereby encourage experimentalists to evaluate the importance of non-additivity in their systems so that the scope and significance of this concern can be adequately assessed. For any type of response variable and any process of inducing nonadditivity, if artifacts are small relative to treatment effects, then any non-additivity is by definition trivial. Unfortunately, artifacts of experimental intervention cannot always be rendered small: for example, Peterson \& Beal (1989) demonstrated that the required enclosing of an estuarine clam enhanced its growth rate by 15 to $21 \%$, about the same magnitude as the 10 to $18 \%$ effect of the density treatment. Likewise, Peterson \& Black (1993) identified a 30 to $105 \%$ increase in growth of another clam inside enclosures as compared to unenclosed clams at the same density. Under the influence of such substantial artifacts, the issue of additivity is not trivial.

The most obvious protocol that would serve to assess the possibility that artifacts of intervention may interact with experimental treatment would be to erect controls for intervention for each separate treatment. Then treatment-specific artifacts of intervention could be measured directly and separated from true treatment effects. Unfortunately, this treatment-by-treatment assessment of artifacts is almost by definition impossible. If the experiments could have been conducted without the intervention, they would have been, thereby sparing the costs of intervention and avoiding the risks of artifact. For the case of addressing the consequences of constraining prey (by tether or enclosure), for example, the constraints are a necessary intervention to permit 
the experiment itself to be conducted. In their absence, migration of the animals would disrupt the intended treatments. For field experiments that employ constraints, it is occasionally possible to conduct a control for the effects of the constraint but for only a single treatment, the one that employs the naturally occurring ambient densities (e.g. see Peterson 1982, Spiller \& Schoener 1988, Peterson \& Beal 1989). For sufficiently mobile or cryptic animals, even this test is impossible.

Although establishment of controls for the intervention process in multiple treatments may be generally impossible, we can suggest an alternative approach. One might be able to vary the frequency, intensity, or specific type of intervention at each of several treatment levels as a means of estimating the artifacts indirectly and thereby drawing conclusions about the likelihood of treatment $\times$ artifact interactions. For example, Peterson (1982) employed a single density treatment in which sampling frequency was halved, as compared to the remainder of the experiment, as a means of testing whether the sampling intervention created any artifacts. Generally, no artifact of the sampling process was detected, but if one had emerged its additivity could have been assessed by varying sampling frequency for more than just the one density treatment. As another example, the presence of an artifact induced by the use of enclosures has been detected in some systems, notably in some experiments with plankton (Gieskes et al. 1979), by manipulating the size of the enclosures and thereby altering the perimeter : area (or wall-surface : enclosure-volume) ratio and presumably also the intensity of the artifact associated with enclosure. The difference in response of a given treatment to changing container size is presumably a consequence of differing magnitudes of the container artifact. If this container artifact is additive, then the magnitude of the difference in artifacts with changing container size should not vary with treatment. A test for additivity could thus be devised by comparing the differences in the size of artifacts as a function of treatment. Kennelly (1983) conducted a test of the artifacts of using small cages to exclude predatory fish by testing whether the use of such cages had any impact when deployed inside much larger cages that already excluded fish. This clever use of cages within cages may be effectively extended to test for interactions between artifacts and experimental treatments.

Another even more satisfying approach to assessing the importance of non-additive artifacts of experimental intervention is one that seeks to understand the actual processes and mechanisms (commonly involving understanding of behavior) by which the artifacts are induced. For example, to evaluate additivity of artifacts associated with tethering, an extension of the approach of Barshaw \& Able (1990a) is appropriate, whereby the actual behavioral mechanisms of artifact induction are investigated. Chapman (1986) conducted a thorough evaluation of potential behavioral artifacts that may be induced by transplantation experiments with gastropods. In general, however, more attention must be given to assessing the predator field (as in Witman 1985 and Wahle \& Steneck 1992) and implications of artifactual prey behavior on relevant predators.

The failure of ecological literature to acknowledge the implicit assumption of additivity of experimental intervention artifacts is surprising given the widespread recognition of the related problem of how to extrapolate from results of experiments to draw generalizations (e.g. Hurlbert 1984, Underwood \& Denley 1984). Ecologists clearly recognize that experimental outcomes may often depend upon the specific conditions under which they were conducted. For example, Underwood (1985) argues compellingly that changing physical conditions in the intertidal shore act to influence community and population structure by altering important biotic interactions. Peterson \& Black (1988) similarly demonstrate the converse that effects of a physical stress, burial by sediments, on a population of clams change with the intensity of crowding. In both of these cases, there is recognition that interactions among physical and biological factors are important in nature and prevent ready extrapolation from results of specific studies. It seems surprising that this recognition of interactions among factors has not been extended to interpretation of individual experiments in a context of potential artifacts of intervention. One cannot accept without challenge the implicit assumption (or occasionally explicit assertion) that because all treatments in an experiment may have been invaded identically the effect is necessarily constant. That is simply not so. Development of tests of the significance and scope of the problem of non-additivity of artifacts of intervention represents a challenge to the creativity of experimentalists.

Acknowledgements. We thank J. E. Duffy, M. E. Hay, S. H Hurlbert, R. T Paine, P. E. Renaud, G. A. Skilleter, and A. J. Underwood for comments on the manuscript. We acknowledge support of the National Science Foundation, both the Biological Oceanography Program and the International Programs (grant \# OCE 86-20210), for support of this work.

\section{LITERATURE CITED}

Abrams, P. A. (1987). Indirect interactions between species that share a predator: varieties of indirect effects. In: Kerfoot, W. Sih, A. (eds.) Predation: direct and indirect impacts on aquatic communities. University Press of New England, Dartmouth, p. 38-54

Ambrose, W. G. Jr, Irlandi, E. A. (1992). Height of attachment 
on seagrass leads to trade-off between growth and survival in the bay scallop Argopecten irradians. Mar. Ecol. Prog. Ser. 90: 45-51

Aronson, R. B. (1987). Predation on fossil and Recent ophiuroids. Paleobiology 13: 187-192

Aronson, R. B. (1988). Palatability of five Caribbean ophiuroids. Bull mar. Sci. 43: 93-97

Aronson, R. B. (1989). Brittlestar beds: low-predation anachronisms in the British Isles. Ecology 70: 856-865

Barshaw, D. E., Able, W. W. (1990a). Tethering as a technique for assessing predation rates in different habitats: an evaluation using juvenile lobsters, Homarus americanus. Fish. Bull. U.S. 88: 415-417

Barshaw, D. E., Able, K. W. (1990b). Deep burial as a refuge for lady crabs Ovalipes ocellatus: comparisons with blue crabs Callinectes sapidus. Mar. Ecol. Prog. Ser. 66: 75-79

Caine, N. G. (1990). Unrecognized anti-predator behaviour can bias observational data. Anim. Behav. 39: 195-197

Chapman, M. G. (1986). Assessment of some controls in experimental transplants of intertidal gastropods. J. exp. mar. Biol. Ecol. 103: 181-201

Connell, J. H. (1974). Field experiments in marine ecology. In: Mariscal, R. (ed.) Experimental marine biology. Academic Press, New York, p. 21-54

Davidson, D. W., Inouye, R. S., Brown, J. H. (1984). Granivory in a desert ecosystem: experimental evidence for indirect facilitation of ants by rodents. Ecology 65: 1780-1786

Dayton, P. K. (1979). Ecology: a science and a religion. In: Livingston, R. J. (ed.) Ecological processes in coastal and marine systems. Plenum Press, New York, p. 3-18

Dayton, P. K., Oliver, J. S. (1980). Problems in the experimental analyses of population and community patterns in benthic marine environments. In: Tenore, K. R., Coull, B. C. (eds.) Marine benthic dynamics. University of South Carolina Press, Columbia, p. 93-120

Gieskes, W. W. C., Kraay, G. W., Baars, M. A. (1979). Current ${ }^{14} \mathrm{C}$ methods for measuring primary production: gross underestimates in oceanic waters. Neth. J Sea Res. 13: $58-78$

Hairston, N. G. Sr (1989). Ecological experiments: purpose, design, and execution. Cambridge University Press, Cambridge

Hay, M. E. (1986). Associational plant refuges: convergent patterns in marine and terrestrial communities result from differing mechanisms. Am. Nat. 128: 617-641

Heck, K. L. Jr, Thoman, T A. (1981). Experiments on predator-prey interactions in vegetated aquatic habitats. J. exp. mar. Biol. Ecol. 53: 125-134

Heck, K. L. Jr, Wilson, K. A. (1987). Predation rates on decapod crustaceans in latitudinally separated seagrass communities: a study of spatial and temporal variation using tethering techniques. J exp. mar. Biol. Ecol. 107: 87-100

Herrnkind, W. F., Butler, M. J. IV (1986). Factors regulating postlarval settlement and juvenile microhabitat use by spiny lobsters Panulirus argus. Mar. Ecol. Prog. Ser. 34: $23-30$

Hurlbert, S. H. (1984). Pseudoreplication and the design of ecological field experiments. Ecol. Monogr. 54: 187-211

Kennelly, S. J. (1983). An experimental approach to the study of factors affectıng algal colonization in a sublittoral kelp forest. J. exp. mar. Biol. Ecol. 68: 257-276

Mclvor, C. C., Odum, W. E. (1988). Food, predation risk, and microhabitat selection in a marsh fish assemblage. Ecology 69: $1341-1351$

Paine, R. T (1977). Controlled manipulations in the marine intertidal zone and their contributions to ecological theory. Spec. Publ. Acad. Nat. Sci. Philadelphia 12: 245-270
Peterson, C. H. (1979). Predation, competitive exclusion, and diversity in the soft-sediment benthic communities of estuaries and lagoons. In: Livingston, R. J. (ed.) Ecological processes in coastal and marine systems. Plenum Press, New York, p. 233-264

Peterson, C. H, (1982). The importance of predation and intra- and interspecific competition in the population biology of two infaunal suspension-feeding bivalves, Protothaca staminea and Chione undatella. Ecol. Monogr. 52: $437-475$

Peterson, C. H., Beal, B. F. (1989). Bivalve growth and higher order interactions: importance of density, site, and time. Ecology 70: $1390-1404$

Peterson, C. H., Black, R. (1988). Density-dependent mortality caused by physical stress interacting with biotic history. Am. Nat. 131: 257-270

Peterson, C. H., Black, R. (1993). Experimental tests of the advantages and disadvantages of high density for two coexisting cockles in a Southern Ocean lagoon. J Anim. Ecol. 62: 614-633

Peterson, C. H., Summerson, H. C., Fegley, S. R., Prescott, R. C. (1989). Timing, intensity, and sources of autumn mortality of adult bay scallops Argopecten irradians concentricus Say. J exp. mar. Biol. Ecol. 127: 121-140

Petraitis, P. S. (1982). Occurrence of random and directional movements of the periwinkle, Littorina littorea (L.). J. exp. mar. Biol Ecol. 59: 207-217

Pilette, R. (1989). Evaluating direct and indirect effects in ecosystems. Am. Nat. 133: 303-307

Power, M. E., Matthews, W. J. (1983). Algal-grazing minnows (Campostoma anomalum), piscivorous bass (Micropterus spp.), and the distribution of attached algae in a small prarie-margin stream. Oecologia 60:328-332

Rabinowitz, D. (1978). Mortality and initial propagule size in mangrove seedlings in Panama. J. Ecol. 66: 45-51

Robertson, A. I. (1986). Leaf burying crabs: their influence on energy flow and export from mixed mangrove forests (Rhizophora spp.) in northeastern Australia. J. exp. mar. Biol. Ecol. 102: 237-248

Rozas, L. P., Odum, W. E. (1988). Occupation of submerged aquatic vegetation by fishes: testing the roles of food and refuge. Oecologia 77: 101-106

Ruiz, G. M., Hines, A. H., Posey, M. H. (1993). Shallow water as a refuge habitat for fish and crustaceans in nonvegetated estuaries: an example from Chesapeake Bay. Mar. Ecol. Prog. Ser. 99: 1-16

Schmitt, R. J. (1987). Indirect interactions between prey: apparent competition, predator aggregation, and habitat segregation. Ecology 68: 1887-1892

Schoener, T W. (1993). On the relative importance of direct versus indirect effects in ecological communities. In: Kawanabe, H., Cohen, J. E., Iwasaki, K. (eds.) Mutualism and community organization. Oxford University Press, Oxford, p. 365-411

Shulman, M. J. (1985). Recruitment of coral reef fishes: effects of distribution of predators and shelter. Ecology 66: $1056-1066$

Smith. T J. III (1.987a). Seed predation in relation to treedominance and distribution in mangrove forests. Ecology 68: $266-273$

Smith, T J. III (1987b). Effects of seed predators and light level on the distribution of Avicennia marna (Forsk.) Vierh. in tropical, tidal forests. Estuar. coast. Shelf Sci. 25: $43-51$

Spiller, D. A., Schoener, T W. (1988). An experimental study of the effect of lizards on web-spider communities. Ecol. Monogr. 58: $57-77$ 
Underwood, A. J. (1985). Physical factors and biological interactions: the necessity and nature of ecological experiments. In: Moore, P. G., Seed, R. (eds.) The ecology of rocky coasts. Hodder \& Stoughton, London, p. 372-390

Underwood, A. J. (1986). The analysis of competition by field experiments. In: Kikkawa, J., Anderson, D. J. (eds.) Community ecology: pattern and process. Blackwell Scientific Press, London, p. 240-268

Underwood, A. J., Denley, E. J. (1984). Paradigms, explanations and generalizations in models for the structure of intertidal communities on rocky shores. In: Strong, D. R., Simberloff, D. S., Abele, L. G., Thistle, A. B. (eds.) Ecological communities: conceptual issues and the evidence. Princeton University Press, Princeton, p. 151-180

Vandermeer, J. (1980). Indirect mutualism: variations on a theme by Stephen Levine. Am. Nat. 116: 441-448

Wahle, R. A., Steneck, R. S. (1992). Habitat restrictions in

This review was presented by A. J. Underwood (Senior

Editorial Advisor), Sydney, Australia early benthic life: experiments on habitat selection and in situ predation with the American lobster. J. exp. mar. Biol. Ecol. 157: 91-114

Watanabe, J. M. (1984). The influence of recruitment, competition, and benthic predation on spatial distributions of three species of kelp forest gastropods (Trochidae: Tegula). Ecology 65: 920-936

Wilson, K. A., Able, K. W., Heck, K. L. Jr (1990). Predation rates on juvenile blue crabs in estuarine nursery habitats: evidence for the importance of macroalgae (Ulva lactuca). Mar. Ecol. Prog. Ser. 58: 243-251

Wilson, K. A., Heck, K. L. Jr, Able, K. W. (1987). Juvenile blue crab, Callinectes sapidus, survival: an evaluation of eelgrass, Zostera marina, as refuge. Fish. Bull. U.S. 85: 53-58

Witman, J. D. (1985). Refuges, biological disturbance, and rocky subtidal community structure in New England. Ecol. Monogr. 55: 421-445

Manuscript first received: September 1, 1993

Revised version accepted: May 2, 1994 